American Journal of Applied Sciences 8 (7): 748-753, 2011

ISSN 1546-9239

(C) 2011 Science Publications

\title{
Research of an Online Service System for Beverages Chain Stores
}

\author{
${ }^{1}$ Chih-Yao Lo, ${ }^{1}$ Cheng-I Hou, ${ }^{1}$ Hsin-Chia Hsu and ${ }^{2}$ Chiu-Ping You \\ ${ }^{1}$ Department of Leisure Management, Yu Da University, Taiwan \\ ${ }^{2}$ Department of Information Management, Yu Da University, Taiwan
}

\begin{abstract}
Problem statement: In the highly competitive market, the availability of consumer support is the key to market-based beverage stores. Consumer demands for quality service so the industry must be more active to improve the quality of management to ensure that beverage market position. In order to allow market competition to be improved for the beverage store. Approach: The system builds an information network using web-based system provides operators and consumers a direct interaction. Enter the phone number provided by the consumer via the Send Message System (SMS) verification code to obtain the online ordering drinks service. Using the Internet Information Technology makes the real-time order so that consumers can enjoy easy ordering and comfortable environment. Results: Using this internet beverage ordering system the online consumers can enjoy the choice of ordering drinks. This internet beverage ordering system would also build some databases to support, such as beverage type database, order database, outgoing regional database, these databases information will enable the industry to conduct drinks promotion strategy adjustments. Conclusion: This study uses cell phone number to enable consumers to obtain authentication codes via SMS. Necessary to convert the current beverage stores different marketing approach, through the information network and Web page interactivity, so that consumers would feel very interesting and fresh.
\end{abstract}

Key words: Beverage store, SMS verification code, internet marketing, consumer behavior, chain stores, information technology, web system, International Franchise Association (IFA), chain or franchise, voluntary chain

\section{INTRODUCTION}

Domestic beverage chain stores have become popular. The beverage chain stores are all over the streets in Taiwan. Consumers will be more diverse selection of beverages; consumer demand will be relatively more diverse (Lahiri, 2010). In the highly competitive market, the availability of consumer confidence will be the key for the beverage chain stores to stand in the markets. The beverage chain stores to win those modern consumers not only pay attention to the quality of drinks and various marketing practices (Estiri et al., 2010) and would more emphasis on service quality and attitude management. Therefore, service quality has become beverage chain stores competitive practices trend. How to make beverage chain stores occupy a position in the market that must pay more attention to drinks and service quality management, so that consumers would increase the loyalty and trust (Lewis, 2005).

According the relevant literature only the consumer behavior for the beverage chain stores has been studied (Crouch et al., 2009). The study is confined the proposal to improve relationship between consumers for the beverage chain stores does not provide how the use of relevant technologies and marketing methods to achieve higher economic profits. To improve the relationship between the consumer (Amine, 2008), if no real way or technology, is unable to achieve increased profits and efficiency. Therefore, in this age of advanced information technology, in addition to strengthening the management of service and quality but also should improve beverage chain stores web information services. The use of Internet technology develops a Web system for the beverage chain stores and use of Internet marketing to attract consumers. To make it provide the latest information, product catalog and enter the phone number through the verification code by SMS to obtain the online beverage $\mathrm{s}$ order function (Deng et al., 2009).

Reference: This study investigated the application of information technology and the Internet website of drinks subscription service system in the beverage chain stores. Therefore, the definition of drinks and classification of chain stores and chain system of the operating pattern of such would be analyses. 
Am. J. Applied Sci., 8 (7): 748-753, 2011

Table 1: Definition of number stores for a chain

\begin{tabular}{lc}
\hline Scholars or organizations & Number of stores \\
\hline Schewe and Smith (1983) & 2 or more \\
Directorate-General of Budget, Accounting and Statistics, Executive Yuan, Taiwan (1997) & \\
Kotler (2000) & 7 or more \\
Chain Development Association in Taiwan (1999) & 10 or more \\
Japan Franchise Association (JFA) (2000) & 11 or more \\
International Franchise Association (IFA) (2000) & \\
\hline
\end{tabular}

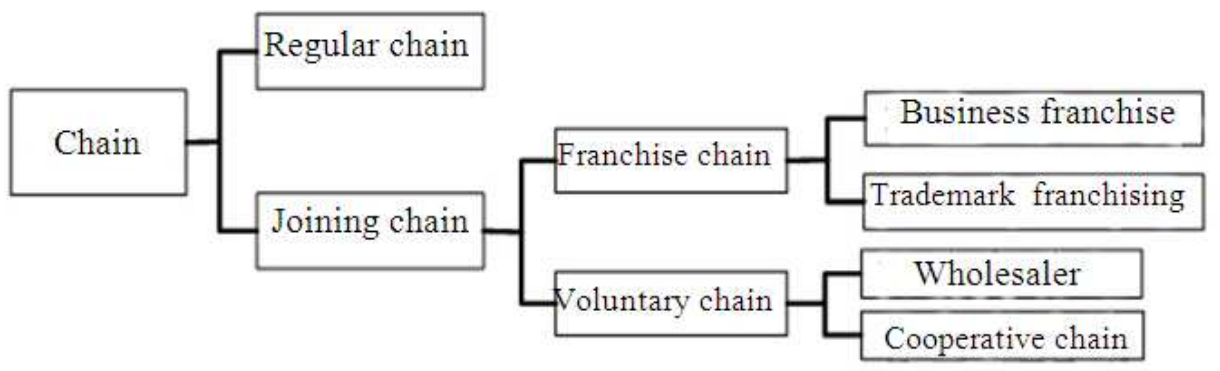

Fig. 1: Chain types

The definition of chain stores: Chain Development Association in Taiwan (1999), the definition and restrictions on chain stores are as follows: The chain stores must have seven or more independent stores. Ye Xiaojing (Yee and Ng, 2011) is defined the chain stores have ten or more stores. Use the same trade names, trademarks, corporate identity system and controlled by the same regional head office or authorized agent. Share a common philosophy and business model and store appearance, layout and decoration, goods, services and shops are all having standard image of the chain or franchise.

According to available literature the definition of chain stores is numerous in domestic and international. They are made from a different point of views. However, domestic experts and scholars or organizations, the definition of the chain stores system and characteristics generally have the same view. They should be the same as the nature of business, store image of a unified and consistent management system and other characteristics. Number of the stores does not seem clear, after analysis shown in Table 1.

This study organizes the experts views on the operating chain store system that chain must have at least 11 (or more) of sales positions. The business model must have a unified corporate identity system (CIS), head of unified planning to be in the same education and training and management system and store decoration and consistency and common business philosophy and mode of operation and management are called chains.

The types and characteristics of chain stores: According to the literature of the chain management (Ranaweera and Prabhu, 2003), depending on the degree of concentration of ownership chain management can be divided into three types, (1)
Regular chain (2) Franchise chain (3) Voluntary chain. Analyzed scholars' research for the chain of ownership concentration on analysis and interpretation of instructions as shown in Fig. 1.

In Fig. 1, the chain can be divided into two categories, which are regular chain and joining chain. The joining chain includes franchise chain and voluntary chain, the discussion is as followed:

Regular chains: This business model is the most common type of chain. According to the U.S. bureau of the census is defined as: "The organization formed with two or more operations of retail stores, operating characteristics of the same and under the same capital, management and product policy." Corporation has the ownership and the corporation responsible for sales, procurement, personnel, inventory and accounting systems of planning and commitment of all branches of the profit and loss. Its purpose is to extend and control of marketing channels and to the overall operation of the concerted action taken to enhance the impression to consumers (Lucian and Farias, 2009) which may also receive benefits of scale and improve overall operating efficiency.

Franchise chains: According to the International Franchise Association (IFA) on the franchise chain is defined as: "a relationship between the franchise headquarters (Franchiser) and franchisees (Franchisee). Franchisors would to give franchisees a license and privileges to enable them to run their businesses and provide organization, training, procurement and management assistance. Also requires relatively franchisees paid a considerable price, as a reward." The revenue of the franchiser headquarter is coming from the Technology fee and franchise fee. 
Am. J. Applied Sci., 8 (7): 748-753, 2011

Table 2: The mode of operation

\begin{tabular}{llll}
\hline Operation Type & Price & Services & Target Market \\
\hline Virtual stores & Low cost & $\begin{array}{l}\text { No time limit and targeted } \\
\text { web surfers and consumers }\end{array}$ & $\begin{array}{l}\text { Limited to the online } \\
\text { population, consumer groups is limited } \\
\text { Pany consumers need to rely on } \\
\text { advertising to attract attention }\end{array}$ \\
Virtual and physical store & High cost and high demand & $\begin{array}{l}\text { Time limited and targeted } \\
\text { pass by consumers } \\
\text { Targeted web surfers and p }\end{array}$ & $\begin{array}{l}\text { Service both consumers } \\
\text { and increased economic }\end{array}$ \\
\hline
\end{tabular}

The purpose of this type chain can combine people who have funds but lack of management capacity together with people who have management techniques but lack of money.

Voluntary chains: Voluntary chain divided into a franchise initiated by the wholesaler and retailer. The purpose is to join the overall purchase to obtain a lower price and then transferred to the other chain retail stores. Such a way to join an organization is similar to the mutually beneficial cooperation in co-existence and common prosperity. Voluntary chain headquarter have their sovereignty, but the franchise chain headquarters would provide the assistance and guidance on business and need to pay franchise fees to the franchisor. The franchise initiated by the retailer is called cooperative chains. Procurement through the establishment of a joint venture unit which bringing together small orders for the franchise of large orders in order to secure preferential purchase price and externally, the name of uniform, joining the retail stores in the name of the same sign hanging and pay a certain amount of advertising costs to expand the business. Hope to reduce costs through cooperative relationships (Kaplan and Haenlein, 2009).

Analysis of the above described types of operations. In the early days of chain stores because of high risk, therefore, most of the chains start small number of stores to franchisees (Zourrig et al., 2009).

The classification of beverage chain stores: Beverage mar ket is currently divided into non-beverage franchise chain stores and franchise chain stores. The franchise chain stores are all the same operating philosophy (Muradian and Pelupessy, 2005), the present study as described in the following four instructions.

- Brand building

- To promote the pursuit of natural health drinks

- The people-oriented services to achieve sustainable development

- Open up to the world
Research methods: The method of this study includes marketing strategy and system development. In marketing strategy, collected more drinks on the chain store literature and research and analysis chain of stores in the beverage drink market and the relationships between consumers. In the system development would focus on to improve existing systems generally order, so as to enhance economic efficiency and profits.

Online beverage marketing strategy: According to the current mode of operation of the existing beverage stores shown in Table 2.

This study would through advertising, publicity DM or product catalogs, website information so that consumers view product information online and also ordering real-time online. Therefore, the consumer groups must be the online users and people who do not want to go out to wait, the consumption is not age restricted. The goal is to improve beverage store current website and enhance direct interaction with consumers. And build an information network based online ordering services to provide a comfortable and relaxing immediate ordering environment.

Beverage online services system: This study uses ASP.NET and SQL Server technologies build the system shown in Fig. 2.

Step explanations:

- The consumer begins ordering through the internet

- The delivery host uses API calling the vendor message host

- SMS host sends the verification to the consumer's cell phone

- The consumer enters the verification code

- The delivery host determines store-order mode, if it is fax then goes to step 7; if it is direct printing then goes to step 6

- The delivery host sends the order through the internet to the store

- The delivery host sends the order to HIFAX host

- HIFAX host sends the fax to the store 
Am. J. Applied Sci., 8 (7): 748-753, 2011

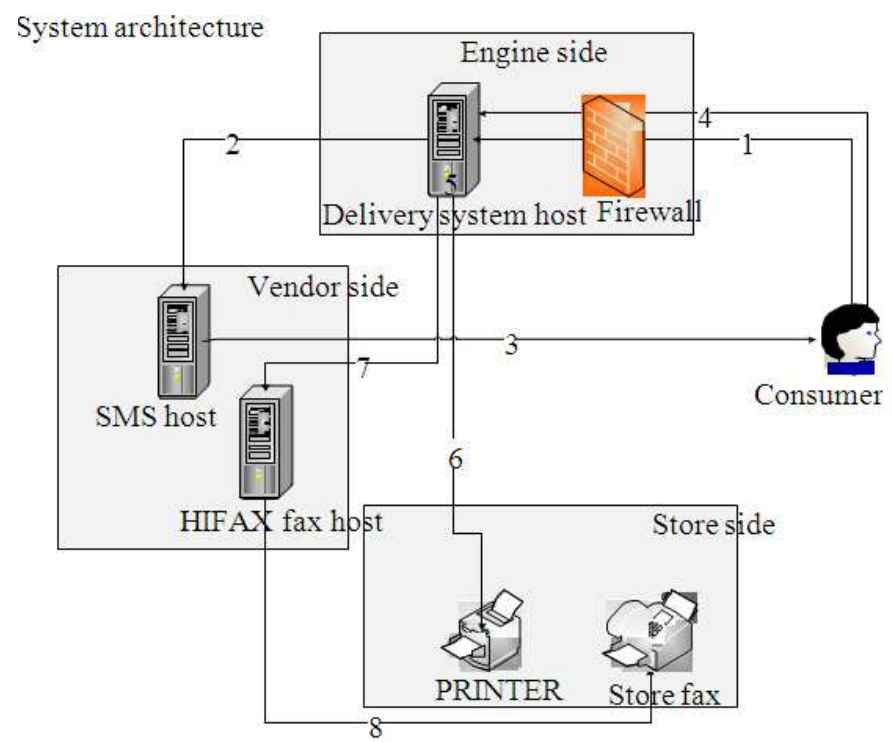

Fig. 2: Overall structure of system operation

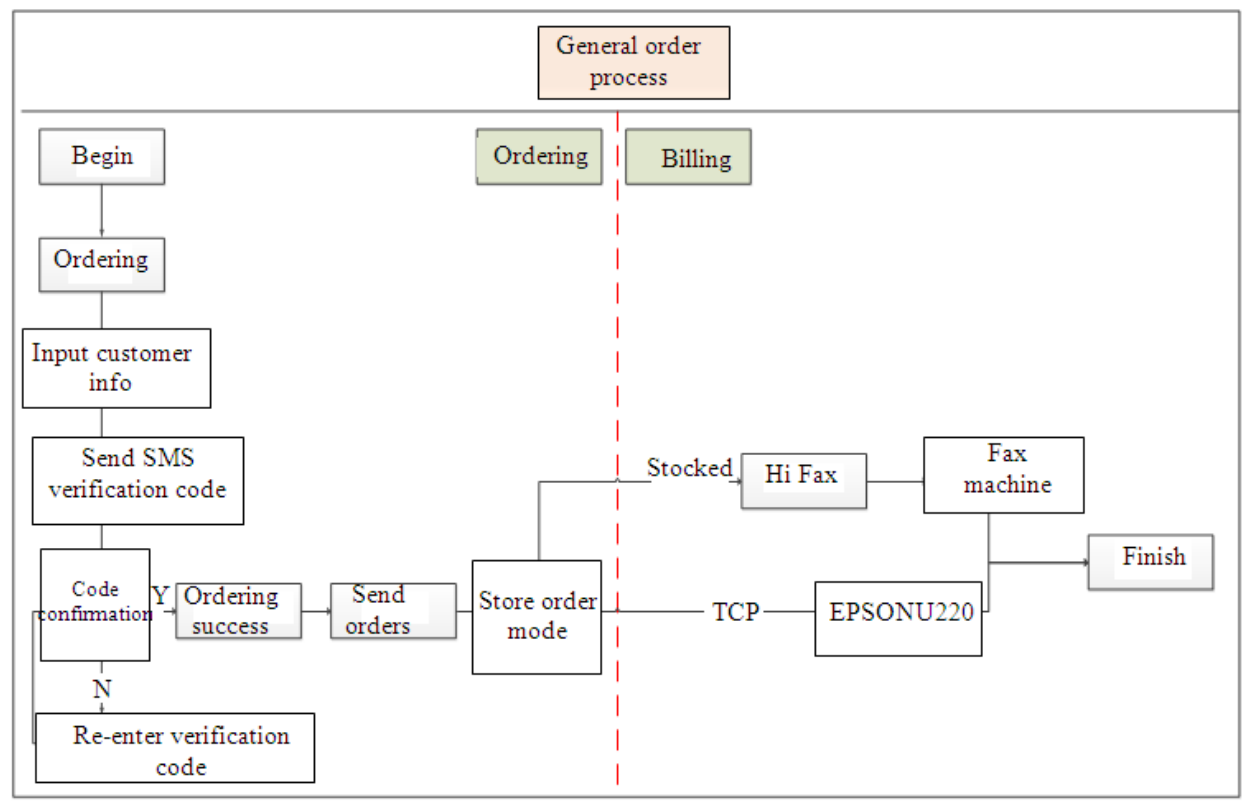

Fig. 3: General Order system processes

This study is based on online beverage ordering service and it is differ from other website which has only store information, product descriptions or other information. The system provides for delivery and takeout services. This ordering services system is the combination of information technology, internet, online services and the three technology systems together. The ordering system is accepted by time and nature of the service, which provides general order and group order, as shown in Fig. 3-4.

This study provides online ordering services for consumers. The system uses of simple information (name, address, phone number) as input and use of mobile phone number to obtain verification code to complete the order procedures. 


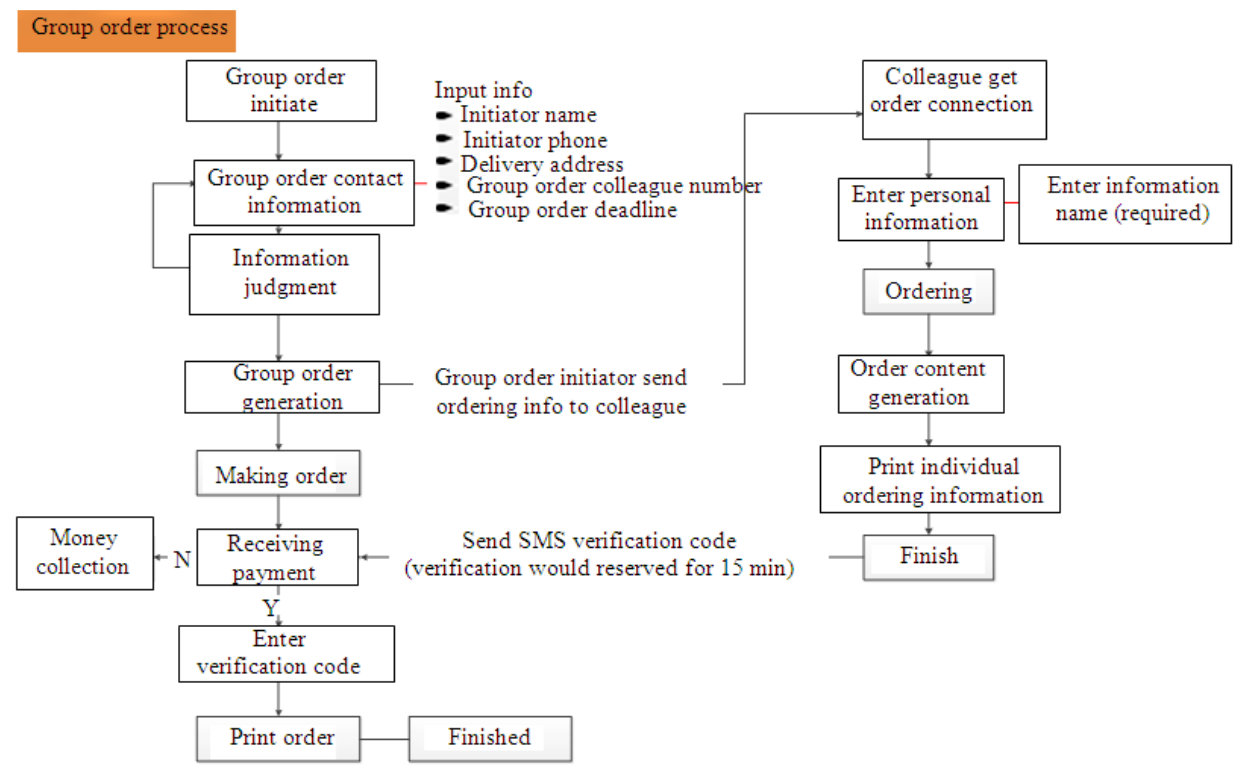

Fig. 4: Groups ordering system processes

\section{RESULTS AND DISCUSSION}

This study would build an online beverage services system and improve current beverage chain store website to enhance the economic profit. Using this internet beverage ordering system the online consumers can enjoy the choice of ordering drinks. The chain stores can increase revenue and sustainable management of the development. This internet beverage ordering system would also build some databases to support, such as beverage type database, order database, outgoing regional database, these databases information will enable the industry to conduct drinks promotion strategy adjustments. The final look of the beverage online ordering system website shows in Fig. 5-7.

In Fig. 5, this is a non-membership system, simply enter the mobile phone number, the system will send SMS to enable consumers to obtain verification code. If customers did not get verification code, next ordering steps is not allowed. An error message page will alert consumers that need to obtain verification code to enter the final order system.

In Fig. 6, the verification code by SMS has received from the mobile phone, it must be complete and correct input into the system. Then the system would allow customer to complete the final order of the program. Consumers can see or print the order details and be able to check with the store beverage items.

In Fig.7, Finally, all ordering information clearly shows that consumers ordered products of the ice level, sweetness, size, number of cups, unit price and total price, etc. and print order form.

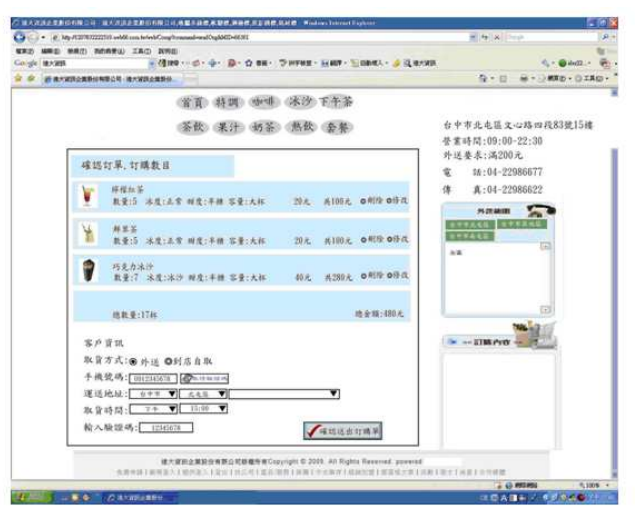

Fig. 5: Beverage online ordering service system website information

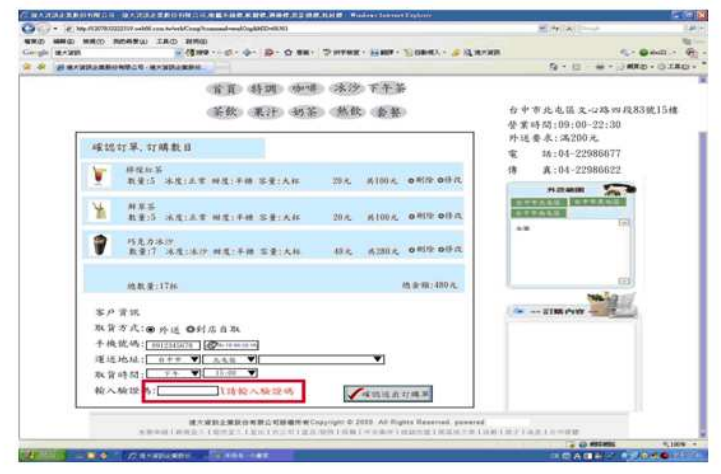

Fig. 6: Method for obtaining the verification code 


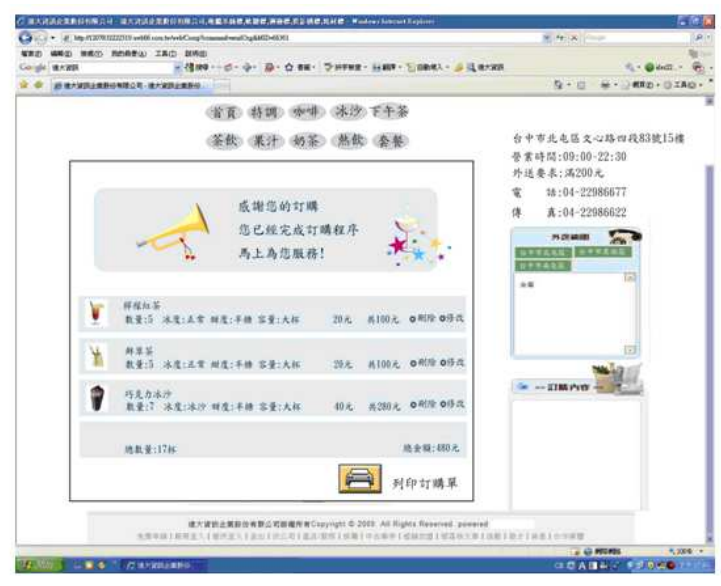

Fig. 7: Final order details screen from the system

\section{CONCLUSION}

Necessary to convert the current beverage stores different marketing approach, through the information network and Web page interactivity, so that consumers would feel very interesting and fresh. This study uses cell phone number to enable consumers to obtain authentication codes via SMS. And use a combination of information technology and the Internet through of real-time beverage ordering system so that consumers can enjoy easy and comfortable beverage ordering environment. Through this marketing approach would improve the quality of management to ensure this beverage chain store have overall market position.

\section{REFERENCES}

Amine, L.S., 2008. Country-of-origin, animosity and consumer response: Marketing implications of antiAmericanism and Francophobia. Int. Bus. Rev., 17: 402-422. DOI: 10.1016/j.ibusrev.2008.02.013

Crouch, G.I., Devinney, T.M., Louviere J.J. and Islam T., 2009. Modeling consumer choice behavior in space tourism. Tourism Manage., 30: 441-454. DOI: 10.1016/j.tourman.2008.07.003

Deng, Z., Y. Lu, K.K. Wei and J. Zhang, 2009. Understanding customer satisfaction and loyalty: An empirical study of mobile instant messages in China. Int. J. Inform. Manage., 30: 289-300. DOI: 10.1016/j.ijinfomgt.2009.10.001
Estiri, M., T. Hasangholipour, H. Yazdani, H.J. Nejad and H. Rayej, 2010. Food products consumer behaviors: The role of packaging elements. J. Applied Sci., 10: 535-543. DOI: 10.3923/jas.2010.535.543

Kaplan, A.M. and M. Haenlein, 2009. The increasing importance of public marketing: Explanations, applications and limits of marketing within public administration. Eur. Manage. J., 27: 197-212. DOI: 10.1016/j.emj.2008.10.003

Lahiri, S., 2010. Assessing the environmental attitude among pupil teachers in relation to responsible environmental behavior: A leap towards sustainable development. J. Soc. Sci., 7: 33-41. DOI: 10.3844/jssp.2011.36.44.

Lewis, M., 2005. Incorporating strategic consumer behavior into customer valuation. J. Market., 69: 230-238. DOI: 10.1509/jmkg.2005.69.4.230

Lucian, R. and S.A. Farias, 2009. Effects of information overload on Brazilian E-consumers. Am. J. Econ. Bus. Admin., 1: 21-26. DOI: 10.3844/ajebasp.2009.21.26

Muradian, R. and W. Pelupessy, 2005. Governing the coffee Chain: The role of voluntary regulatory systems. World Dev., 33: 2029-2044. DOI: 10.1016/j.worlddev.2005.06.007

Ranaweera, C. and J. Prabhu, 2003. The influence of satisfaction and trust and switching barriers on customer retention in a continuous purchasing setting. Int. J. Service Industry Manage., 14: 374395. DOI: $10.1108 / 09564230310489231$

Yee, J. and C.S. Ng, 2011. Consumers' perceived quality, perceived value and perceived risk towards purchase decision on automobile. Am. J. Econ. Bus. Admin., 3: 47-57. DOI: 10.3844/ajebasp.2011.47.57

Zourrig, H., J.C. Chebat and R. Toffoli, 2009. Consumer revenge behavior: A cross-cultural perspective. J. Bus. Res., 62: 995-1001. DOI: 10.1016/j.jbusres.2008.08.006 